\title{
REDUCTION OF INCIDENCE AND SEVERITY OF Septoria lycopersici LEAF SPOT OF TOMATO WITH BACTERIA AND YEASTS
}

\author{
REDUÇÃO DA INCIDÊNCIA E SEVERIDADE DA MANCHA FOLIAR DO TOMATEIRO \\ CAUSADA POR Septoria lycopersici COM BACTERIA E LEVEDURAS
}

\author{
Luiz Eduardo Bassay Blum ${ }^{1}$
}

\section{SUMMARY}

Septoria leaf spot, caused by Septoria lycopersici, is an important disease of tomato (Lycopersicon esculentum) which is mainly controlled by fungicide sprays. One of the alternatives to reduce fungicide applications is the use of leaf antagonists such as yeast and bacterium. This study was conducted from 1994 through 1995 in Auburn, AL, USA. The pathogen and one antagonist were isolated from field plants. In greenhouse, six yeast and one bacterial isolates were tested, in a set of seven experiments. The experiments were conducted in a completely randomized design with four to eight treatments and six replications. The antagonists $\left(1-3 \times 10^{8}\right.$ colony forming units $\mathrm{ml}^{\mathrm{I}}{ }^{1}$ ) were inoculated $48 \mathrm{~h}$ before the inoculation of the pathogen $\left(1-2 \times 10^{5}\right.$ conidia $\left.\mathrm{ml}^{-1}\right)$, under conditions of intermittent misting. The yeast isolate Y236 (Cryptococcus laurentii) and the bacterial isolate BTL (Pseudomonas putida) significantly $(P \leq 0.05)$ reduced the incidence or the severity of the disease in most experiments.

Key words: Biological control, septoria leaf spot, septoria leaf blight, tomato.

RESUMO

A mancha foliar causada pelo fungo Septoria lycopersici é uma doença no tomateiro (Lycopersicon esculentum), controlada basicamente pela aplicação de fungicidas. Uma das alternativas ao controle químico dessa enfermidade é a utilização de bactérias e leveduras antagonistas. Este estudo foi conduzido de 1994 a 1995 em Auburn, Alabama, EUA. O patógeno e um dos antagonistas foram isolados do filoplano de plantas de tomateiro infectadas pela doença em questão. Sete antagonistas (um isolado de bacteria e seis de leveduras) foram testados em uma série de sete experimentos conduzidos em casa de vegetação. Os experimentos foram conduzidos em um delineamento completamente casualizado com quatro a oito tratamentos e seis repetições. Em todos os experimentos, os antagonistas $\left(1-3 \times 10^{8}\right.$ unidades formadoras de colonia $\mathrm{ml}^{-1}$ ) foram inoculados $48 \mathrm{~h}$ antes da inoculação com o patógeno $\left(1-2 \times 10^{5}\right.$ conidios $\left.\mathrm{ml}^{-1}\right)$, sob condições de nebulosidade intermitente. Entre os antagonistas testados, destacaram-se o isolado de levedura Y236 (Cryptococcus laurentii) e o isolado bacteriano BTL (Pseudomonas putida). Ambos os isolados reduziram significativamente $(P \leq 0.05)$ a incidência $e a$ severidade da doença na maioria dos experimentos.

Palavras-chave: Controle biológico, mancha de septoria, queima de septoria, tomate.

\section{INTRODUCTION}

The septoria leaf spot of tomato (Lycopersicon esculentum) is caused by Septoria lycopersici. This disease is important on cultivated tomato around the world (STEVENSON, 1991). It was first reported in Argentina in 1882 and later in the United States in 1896 (SUTTON \& WATERSTON, 1966). The importance of this disease depends on weather conditions, being favored by high moisture and temperatures. In these conditions it can cause severe defoliation and consequently significant yield losses due to sun scald of the fruits (STEVENSON, 1991; FERRANDINO \& ELMER, 1992). LINCOLN \& CUMMINS (1949), in the USA, reported $80 \%$ defoliation and SOHI \& SOKHI (1974) in India reported almost $100 \%$ defoliation, due to septoria leaf spot. ERINLE $\boldsymbol{e t}$ al. (1986) reported that in Northern Nigeria S. lycopersici was the only serious problem, during three consecutive years, in unprotected tomato cultivars.

\footnotetext{
${ }^{1}$ Engenheiro Agrônomo, Ph.D., Professor do Departamento de Fitotecnia, Centro de Ciências Agroveterinárias, Universidade do Estado de Santa Catarina, CP 281, 88520-000, Lages, SC. E-mail: a2lbb@ cav.udesc.br.
} 
The symptoms of this disease are circular to elliptical lesions, with a dark-gray center, surrounded by a yellow halo, particularly on older leaves. Pycnidia are produced in the center of the lesions. Usually the spots coalesce, followed by leafyellowing and defoliation. The pathogen is characterized by dark-brown pycnidia and multicellular hyaline filiform conidia. Tomato plant debris and solanaceous weeds are the source of inoculum, from which conidia are disseminated mainly by rain splash (TOKESHI \& CARVALHO, 1980).

Recommendations for control of this disease include fungicide sprays, crop rotation, resistant cultivars, and removal of susceptible weeds (Solanum carolinense, Physalis sp., Datura stramonium, etc.) and plant debris (BHARDWAJ $\boldsymbol{e t}$ al., 1995; ERINLE et al., 1986; MALNATI, 1993; STEVENSON, 1991; TEDLA, 1985). One alternative to control this disease is the use of antagonistic microorganisms. This biological control method would reduce the necessity of fungicide sprays, decreasing the risks of the selection of fungicide resistant strains $(\mathrm{COOK} \&$ BAKER, 1983). There have been some successful reports using microorganisms to control other species of Septoria including, S. musiva (Mycosphaerella populorum) leaf spot of poplar (Populus spp.) with the fungus Phaeotheca dimorphospora (YANG et al., 1994), and $\boldsymbol{S}$. tritici using fluorescent Pseudomonas spp. (LEVY et al., 1988, 1989). Nevertheless, little or no information has been published concerning the biological control of $S$. lycopersici (BLUM et al., 1996). Thus, the objectives of this work were to select antagonists and to evaluate their efficacy in controlling the pathogen $S$. lycopersici on tomato under greenhouse conditions.

\section{MATERIAL AND METHODS}

This study was conducted from July 1994 through July 1995 at the greenhouse of the Auburn University Biological Control Laboratory, Department of Plant Pathology, Auburn, AL, USA. The pathogen was isolated from naturally infected field tomato leaves. Conidia of $\boldsymbol{S}$. lycopersici were isolated directly from pycnidia produced on leaf lesions. These conidia were plated in potatodextrose-agar (PDA, Difco Lab., Detroit, MI, USA), amended with $100 \mathrm{mg} \mathrm{L}^{-1}$ of streptomycin sulfate to suppress bacteria. Pure Septoria cultures were grown on PDA at room temperature $\left(24^{\circ} \mathrm{C} \pm 2^{\circ} \mathrm{C}\right)$ for three to four weeks before they were used for inoculations. The fungus was preserved in tubes containing PDA at $10^{\circ} \mathrm{C}$ (Precision Scientific - GCA Corp., Chicago, IL, USA).

For all experiments, three to four-weekold cultures were used as source of inoculum of the pathogen. Ten $\mathrm{ml}$ of sterile water were poured on each culture plate and then scraped to remove the conidia. The suspension was filtered through a double layer cheesecloth and diluted to provide concentrations of $4-5 \times 10^{4}$ or $1-2 \times 10^{5}$ conidia ml $^{1}$, after conidia concentration readings in a Neubauer spore counting chamber. These concentrations were chosen as mean values from the ones cited in the literature (ELMER \& FERRANDINO, 1995; MALNATI, 1993; MALNATI et al.,1993). Pathogen inoculum, as a conidial suspension, was spray inoculated using a one-liter capacity hand sprayer.

Yeast isolates, Y178 (Candida tenuis), Y180 (C. oleophila), Y182 (C. oleophila), Y211 (Debaryomyces hansenii), Y236 (Cryptococcus laurentii), and Y239 (C. laurentii) were obtained from Dr. Charles Wilson (USDA/ARS, Appalachian Fruit Research Station, Kearneysville, WV,USA.) and the bacterial isolated BTL (Pseudomonas putida) was collected from Septoria infected tomato leaf tissue and isolated on tryptic-soy-agar (TSA, Difco). These microorganisms were stored in tubes of appropriate media (MEA or TSA) in an incubator at $10^{\circ} \mathrm{C}$ (Precision Scientific - GCA Corp.) and in tryptic soy broth (Difco) amended with $15 \%\left(\mathrm{v} \mathrm{v}^{-1}\right)$ glycerol at $-80^{\circ} \mathrm{C}$. The bacterial isolate was identified by the Gas Chromatograph Fatty Acid Methyl-Ester analyses method (ROY, 1988; STEAD, 1988), performed by the Laboratory of Bacteriology, Department of Plant Pathology, Auburn University, Auburn, AL, USA.

Tomato 'Rutgers' seedlings were grown in horticultural organic potting mix (Promix BX, Premier Brand, New Rochelle, NY, USA). The plants were transplanted to the final pots (1L black plastic pots) at 30-35 days of age, and fertilized with $10 \mathrm{~g}$ of 14-14-14 N-P-K (Osmocote, Grace-Sierra Horticultural Products Co., Milpitas, CA, USA) per pot. Ten days after transplanting these tomato plants (40-45 days old) were used in the experiments.

The antagonists were cultivated on MEA or TSA for $48 \mathrm{~h}$ and then scraped and suspended in sterilized distilled water. The suspension was filtered through a double layer cheesecloth to avoid media particles in the suspension. Forty-eight hours before the pathogen, all antagonists were inoculated at a concentration of $1-3 \times 10^{8}$ colony forming units 
(CFU) $\mathrm{ml}^{-1}$ by spray application. This antagonists concentration was chosen based on previously reported data (KORSTEN et al., 1995; POTJEWIJD et al., 1995; PUSEY, 1989; WILSON et al., 1993). The concentrations of antagonists were adjusted based on previously prepared equations, correlating optical density (560nm for bacteria and $350 \mathrm{~nm}$ for yeast isolates) readings in a spectrophotometer (Spectronic 601 - Milton Roy Co. Analytical Products Division, Rochester, $\mathrm{NY}$, USA) and CFUml ${ }^{-1}$. Colonies were enumerated by spiral-plating (Spiral System Instruments, Bethesda, MD, USA) antagonists suspensions on petri dishes with MEA or TSA, and counting the formed colonies, two days later, using a laser colony scanner (Model 500 A, Spiral System Instruments). For the yeast isolates optical density $(350 \mathrm{~nm})$ of 1.5 resulted in population density of 2 $2.5 \times 10^{8} \mathrm{CFUml}^{-1}$, and for the bacterial isolate optical density $(560 \mathrm{~nm})$ of 0.1 resulted in concentration of 1-1.5 $\times$ $10^{8} \mathrm{CFUml}^{-1}$. After the inoculation of antagonists, plants were maintained under intermittent misting conditions, and under a temperature regime of $25^{\circ} \mathrm{C}$ $\left( \pm 5^{\circ} \mathrm{C}\right)$.

Disease evaluation was carried out by counting the number of lesions leaflet ${ }^{-1}(10-30$ leaflets plant $^{-1}$ ) and by the percentage of infected leaflets plant $^{-1}$. The experiments were in a completely randomized design, with six replications and four to eight treatments. Each replication was represented by one tomato plant. Details of each experiment are presented on tables 1 and 2 . The data were analyzed by one way ANOVA test, and the averages were compared by Fisher's Protected LSD test $(\mathrm{P} \leq$ 0.05) (FORTHOFER \& LEE, 1995). SigmaStat v.2 (SPSS / Jandel Scientific Software, Chicago, IL, USA) and StatView v.4.53 (Abacus Concepts, Berkeley, CA, USA) were used for processing the data.

\section{RESULTS AND DISCUSSION}

The greenhouse experimental data showed that it is possible to reduce the incidence or severity of the septoria induced disease on tomato by using beneficial leaf colonizing organisms. In the first biocontrol experiment only the yeast isolate
Y236 (Cryptococcus laurentii) significantly ( $\mathrm{P} \leq$ 0.05 ) reduced the number of leaf spots and the incidence of the disease (Table 1). In the second experiment the most efficient microorganisms were Y178 (Candida tenuis) and Y180 (C. oleophila) (Table 1). However, in the third experiment, only isolates Y182 (C. oleophila) and BTL (Pseudomonas putida) significantly $(\mathrm{P} \leq 0.05)$ reduced the incidence of septoria leaf spot (Table 1). This study is one of the firsts attempts to control Septoria lycopersici with leaf antagonists. Thus, differences on the results from test to test are expected. These variations in results are normal in biological control trials, even under controlled greenhouse conditions (BLUM \& LIN, 1991). The difficulties involved in the determination of the correct combination of inoculum concentration, time of application, formulation, survival, adaptation to the environment, and competitive capacity of the antagonists, might be some of the reasons for these variations in the efficiency of the biological control agents (COOK \& BAKER, 1983; DIK et al., 1992). Combinations of treatments (biological and 
Table 2 - Incidence (I) and severity of Septoria lycopersici leafspot on 'Rutgers' tomato, 30 days after the inoculation of the pathogen in plants pre-treated with antagonists.

\begin{tabular}{|c|c|c|c|c|}
\hline \multirow{2}{*}{$\begin{array}{l}\text { Antagonist } \\
\text { Treatment }\end{array}$} & \multicolumn{2}{|c|}{ Experiment $6^{(1)}$} & \multicolumn{2}{|c|}{ Experiment $7^{(2)}$} \\
\hline & $I(\%)^{(3)}$ & Severity ${ }^{(4)}$ & $I(\%)^{(3)}$ & Severity $^{(4)}$ \\
\hline none (control) & 57.8 & 59.0 & 7.2 & 5.5 \\
\hline Y180 & 52.8 & 50.5 & 6.7 & $2.8^{*}$ \\
\hline Y236 & $30.6^{*}$ & 31.0 & 5.6 & $2.0^{*}$ \\
\hline BTL & $20.0 *$ & $15.2 *$ & $1.1 *$ & $0.3 *$ \\
\hline BTL (0.5 dose) & $22.2 *$ & $11.5^{*}$ & 6.1 & $1.8^{*}$ \\
\hline $\operatorname{PLSD}(5 \%)^{(5)}$ & 16.8 & 29.3 & 2.0 & 1.7 \\
\hline
\end{tabular}

${ }^{(1)}$ Pathogen inoculated at $2 \times 10^{5}$ conidia $\mathrm{ml}^{-1} ;{ }^{(2)}$ Pathogen inoculated at $4 \times 10^{4}$ conidia $\mathrm{ml}^{-1}$;

${ }^{(3)}$ Percentage of incidence relative to 30 leaflets plant ${ }^{-1} ;{ }^{(4)}$ Number of spots 30 leaflets $^{-1}$ plant $^{-1}$;

${ }^{(5)}$ Fischer's Protected Least Significant Difference (*Average of the treatment differs from control without antagonists).

chemical) could reduce these variations in results. JANISIEWISCZ et al. (1998) reported a better control of the blue mold decay of apple (Penicillium expansum) combining calcium chloride $\left(\mathrm{CaCl}_{2}\right)$ with the antagonist Pseudomonas syringae (isolate ESC-11).

Isolate Y236, which significantly reduced disease in the first experiment (Table 1), was not significantly $(\mathrm{P} \leq 0.05)$ different from the control in the second and third experiments (Table 1), but significantly reduced disease severity or incidence from the fifth through the seventh experiments (Tables 1 and 2). Some of the isolates of Candida oleophila, Cryptococcus laurentii and $\boldsymbol{P}$. putida are reported phyllosphere antagonists (COOK \& BAKER, 1983; FOKKEMA \& LORBEER, 1974; FOKKEMA \& VAN DER MEULEN, 1976; McGUIRE \& BALDWIN, 1994; WILSON et al., 1993). These microorganisms could be competing for nutrients and sites of action, parasitizing or inhibiting S. lycopercici. Possible mechanisms of antagonism should be investigated later. CASTORIA et al. (1997) reported that $\boldsymbol{C}$. laurentii (LS-28) acted against $\boldsymbol{P}$. expansum (apple blue mold) and Botrytis cinerea (apple gray mold) by competing for nutrients and by producing high levels of extracellular beta-1,3-glucanase activity when grown in the presence of the cell walls of the pathogens. In addition, these authors informed that under their experimental conditions, antibiosis did not appear to be involved in the activity of the antagonist (C. laurentii LS-28).

The fourth and fifth experiments confirmed the efficiency of BTL (P. putida) in significantly reducing $(\mathrm{P} \leq 0.05)$ the number and incidence of septoria leaf spot (Table 1). In addition, the isolates Y180 (C. oleophila) and Y236 presented less disease than the control in these experiments (Table 1). The isolate BTL, considered efficient before (Table 1), once more reduced the disease severity and incidence in the sixth and seventh experiments (Table 2). In these experiments, BTL significantly $(\mathrm{P} \leq 0.05)$ reduced the disease incidence and severity in two different rates of its application (Table 2). Possibly, in combination with other mechanisms of biological control, the preemptive consume of some critical nutrient by these phylloplane antagonists could reflect in less growth of the pathogen and hence less disease (BLAKEMAN, 1985; COOK \& BAKER, 1983), even though this mechanism was not evaluated in this study. In addition to the evaluation of the incidence and severity of disease, the size of the lesions and the population of the pathogen on leaf surface should be rated. These parameters combined could decrease disease assessment analyses variability in biological control experiments.

From these data, at least under greenhouse conditions, it is possible to conclude that some of the tested isolates, Y236 (C. laurentii) and BTL (P. putida), have potential to reduce the severity and incidence of septoria leaf spot. Nevertheless, studies on antagonists inoculum concentration, antagonists formulation, antagonists doses, time for antagonists application, antagonists optimum environment, antagonists survival on leaf surface, and combinations of antagonists and chemical substances should be developed to minimize variations in the results of biological control trials.

\section{ACKNOWLEGMENTS}

The author is thankful to Dr. Mark Wilson (Dept. Biology, The Colorado College, Colorado Springs, CO, USA) for suggesting improvements to this paper, to Dr. Charles Wilson (USDA/ARS, Appalachian Fruit Res. St., Kearneysville, WV, USA.) for furnishing the yeast isolates, and to John McInroy (Dept. Plant Pathology, Auburn University, Auburn, AL, USA) for bacterial identifications.

\section{REFERENCES}

BHARDWAJ, C.L., THAKUR, D.R., JAMWAL, R.S. Effect of fungicide spray and staking on diseases and disorders of tomato (Lycopersicon esculentum). Indian Journal of Agricultural Sciences, New Delhi, v.65, n.2, p.148-151, 1995.

BLAKEMAN, J.P. Ecological succession of surface leaf microorganisms in relation to biological control. In. WINDELS, C.E., LINDOWN, S.E. Biological control on the phylloplane. St. Paul : APS, 1985. p.6-30. 
BLUM, L.E.B., LIN, M.T. Potencial de Trichoderma e Pseudomonas fluorescentes para o controle do tombamento de mudas causado por Cylindrocladium spp. Fitopatologia Brasileira, Brasília, v.16, n.1, p.71-74, 1991.

BLUM, L.E.B.; WILSON, M., BACKMAN, P.A. Biological control of Septoria lycopersici with epiphytic bacteria and yeasts under greenhouse. Phytopathology, St. Paul, v.86, supplement, p.s37, 1996.

CASTORIA, R., DE CURTIS, F., LIMA, G., et al. Beta-1,3glucanase activity of two saprophytic yeasts and possible mode of action as biocontrol agents against postharvest diseases. Postharvest Biology and Technology, v.12, n.3, p.293-300, 1997.

COOK, R.J., BAKER, K.F. The nature and practice of biological control of plant pathogens. St Paul :APS, 1983. 539p.

DIK, A.J., FOKKEMA, N.J., VANPELT, J.A. Influence of climatic and nutritional factors on yeast population-dynamics in the phyllosphere of wheat. Microbial Ecology, Wageningen, v.23, n.1, p.41-52, 1992.

ELMER, W.H., FERRANDINO, F.J. Influence of spore density, leaf age, temperature, and dew periods on septoria leaf spot of tomato. Plant Disease, St. Paul, v.79, n.3, p.287-290, 1995.

ERINLE, I.D.; QUINN, J.G., OYEJOLA, B. Effect of a fungicide spray program on performance of ten tomato cultivars in Northern Nigeria. Tropical Pest Management, London, v.32, n.2, p.111-114, 1986.

FERRANDINO, F.J., ELMER, W.H. Reduction in tomato yield due to Septoria leaf spot. Plant Disease, St. Paul, v.76, n.2, p.208-211, 1992

FOKKEMA, N.J., LORBEER, J.W. Interactions between Alternaria porri and the saprophytic mycoflora of onion leaves. Phytopathology, St. Paul, v.64, n.8, p.1128-1133, 1974.

FOKKEMA, N.J., VAN DER MEULEN, F. Antagonism of yeastlike phyllosphere fungi against Septoria nodorum on wheat leaves. Netherlands Journal of Plant Pathology, Wageningen, v.82, n.1, p.13-16, 1976.

FORTHOFER, R.N., LEE, E.S. Introduction to biostatistics: a guide to design, analysis, and discovery. San Diego, Academic, 1995. 567p.

JANISIEWICZ, W.J., CONWAY, W.S., GLENN, D.M., et al. Integrating biological control and calcium treatment for controlling postharvest decay of apples. HortSience, Alexandria, v.33, n.1, p.105-109, 1998.

KORSTEN, L., De JAGER, E.S., De VILLIERS, E.E., $\boldsymbol{e}$ t al Evaluation of bacterial epiphytes isolated from avocado leaf and fruit surfaces for biocontrol of avocado postharvest diseases. Plant Disease, St. Paul, v.79, n.11, p.1149-1156, 1995.

LEVY, E., EYAL, Z., CHET, I. Suppression of Septoria tritici blotch and leaf rust on wheat seedling leaves by pseudomonads. Plant Pathology, Oxford, v.37, n.4, p.551557,1988 .

LEVY, E., EYAL, Z., CARMELY, S., et al. Suppression of Septoria tritici and Puccinia recondita of wheat by an antibiotic-producing fluorescent pseudomonad. Plant Pathology, Oxford, v.38, n.4, p.564-570, 1989.

LINCOLN, R.G., CUMMINS, G.B. Septoria blight resistance in tomato. Phytopathology, St. Paul, v.39, p.647-655, 1949.

MALNATI, W. D., INOUE, A. K., MESQUITA F ${ }^{\mathrm{o}}$, M. C., $\boldsymbol{e} \boldsymbol{t} \boldsymbol{a l}$. Metodologia de avaliação da resistência de Lycopersicon spp a Septoria lycopersici. Fitopatologia Brasileira, Brasília, v.18, n.1, p.34-41, 1993.

MALNATI, W.D. Possibilidades de inclusão da resistência genética no controle da septoriose do tomateiro. Fitopatologia Brasileira, Brasília, v.18, n.4, p.469-477, 1993.

McGUIRE, R.G., BALDWIN, E.A. Compositions of cellulose coatings affect populations of yeasts in liquid formulation and coated grapefruits. Proceedings of Florida State Horticultural Society, v.107, p.293-296, 1994.

POTJEWIJD, R., NISPEROS, M.O., BURNS, J.K., et al. Cellulose-based coatings as carriers for Candida guillermondii and Debaryomyces sp. In reducing decay of oranges. HortScience, Alexandria, v.30, n.7, p.1417-1421, 1995 .

PUSEY, P.L. Use of Bacillus subtilis and related organisms as biofungicides. Pesticide Science, W. Sussex, n.27, p.133$140,1989$.

ROY, M.A. Use of fatty acids for the identification of phytopathogenic bacteria. Plant Disease, St. Paul, v.72, n.5, p.460, 1988 .

SOHI, M.S., SOKHI, S.S. Morphological, physiological and pathological studies in Septoria lycopersici. Indian Phytopathology, New Delhi, v.26, n.4, p.666-673, 1974.

STEAD, D.E. Identification of bacteria by computer-assisted fatty acid profiling. Acta Horticulturae, Wageningen, n.225, p.39-46, 1988 .

STEVENSON, W.R. Septoria leaf spot. In: JONES, J.B., JONES, J.P., STALL, et al. Compendium of tomato diseases. St. Paul : APS, 1991. p.22.

SUTTON, B.C., WATERSTON, J.M. Septoria lycopersici. Kew: Commonwealth Mycological Institute, 1996. N.89: Descriptions of pathogenic fungi and bacteria: p.1-2.

TEDLA, T. Effect of captafol and ridomil (R) Mz in the control of late blight (Phytophthora infestans) and septoria leaf spot (Septoria lycopersici) on tomato. Acta Horticulturae, Wageningen, n.158, p.389-399, 1985.

TOKESHI, H., CARVALHO, P.C.T. Doenças do tomateiro Lycopersicum esculentum Mill. In: GALLI, F. Manual de fitopatologia - doenças das plantas cultivadas. São Paulo : Agronômica Ceres, 1980. V.2. Cap.35. p.511-532.

WILSON, C.L., WISNIEWSKI, M.E., DROBY, S., et al. A selection strategy for microbial antagonists to control postharvest diseases of fruits and vegetables. Scientia Horticulturae, Amsterdam, v.53, n.3, p.183-189, 1993.

YANG, D., BERNIER, L., DESSUREAULT, M. Biological control of Septoria leaf spot of poplar by Phaeotheca dimorphospora. Plant Disease, St. Paul, v.78, n.8, p.821$825,1994$. 